\title{
Iranian EFL Teachers' Challenges with the New ELT Program after the Reform: From Dream to Reality
}

\author{
Parvin Safari ${ }^{1}$ \\ Shiraz University, Iran \\ Rahman Sahragard \\ Shiraz University, Iran
}

\section{Introduction}

In each country, progress in education plays a significant role in human development, socio-economic growth, equal opportunities, accessibility of skillful human power, more welfare, and political stability (Rena, 2008). This view has led policy makers around the world to enormous ly invest in education (Rena, 2011) and make any attempt to create basic changes in the texture of education for further prosperity. Thus, to drive in this path, educational transformations and reform in curriculum are required to reflect the changes in educational theories and praxis of the modern world (Fterniati, 2006).

The success of any reform is guaranteed through effective policies, well-devised plans, and great efforts of policy makers, curriculum developers, textbook writers, educators, and all stakeholders to implement new reforms in the educational system. Actually, along with any successful reform, the pedagogical features and content of instruction will undergo dramatic changes (Porter, Archbald, \& Tyree, 1991). The former educational system of Iran also suffered a lack of efficacy to meet the students'needs in developingskills and capabilities; in addition, it was incapable of competing with other educational systems around the world, regarding the theoretic al and pedagogical advancements based on the recent research findings. Hence,a major reform in the educational system in the late 2012 took place which changed the number of grades and textbooks in schools (Safari \&Rashidi, 2015b).

The significance of language curriculum in primary education cycles is obvious for each government (Janfeshan\&Nosrati, 2014). Thus, the language program as a key

\footnotetext{
${ }^{1}$ Corresponding author
} 
component of this major reform was not an exception as the state English textbooks which were on the basis ofarchaic methods and old-fashioned theories such as grammar translation, rote memorization, mechanical drills, and repetition wereentirely changed.

Since the ELT program of Iran failed to enhance students' language development for use in authentic communicative situations and empower the graduated students from high schools for effective language communication (Safari \& Rashidi, 2015b) prior to the educational reform, the newly designed English textbooks named as "English for School Series, Prospect"aim to develop students'oral skills, language use, and communication proficiency in real life situations. However, to achieve this end, according to Janfeshan and Nosrati (2014),communicative Language Teaching (CLT) as the central method for application of Prospect was introduced by the Ministry of Education of Iran through teacher training programs, and language instruction based on Prospect was associated with different types of Iranian EFL teachers' feedback during first months of its initiation.In this study, the researchers make an attempt to explore the Iranian EFL teachers' challenges, concerns, and problems through the process of revolutionaryreform to teach Prospect series in the Ministry of Education.

\section{A revie w of related lite rature}

\subsection{The ELT program before the Islamic Revolution}

In Iran, the educational system falls under the jurisdiction of the Ministry of Education which is of main authority in determining all plans, decisions,curricula and policies (Safari \&Rashidi, 2015a). In public schools, all the educational policies and decisions including designing and publication of textbooks, curriculum principles, educational standards, system of examination, (Aslanabadi\&Aslanabadi, 2013; Ghorbani, 2007; Safari \&Rashidi, 2015b) and even teachers' salaries are made by the Ministry of Education which are transferred to the organizations located in each province.

The structure of educational system involves four cycles, as Pre-primary school, Primary, Middle (junior high school), and Secondary (high school) cycles. During Pahlavi era, the system of education was based on the French secular system in which students were engaged in studying one year in pre-primary, six years in primary, three years in middle, and three years in secondary education cycles respectively.The goal of Iranian students' engagement with such teaching system prepared them for occupations such as science, administration, management, and foreign languages. 
According to Foroozandeh (2011), the history of ELT education dates back to 1939 when Native Speakers of Persian(NSP) and Native Speakers of English (NSE)researchers and practitioners had the responsibility for designing, writing and publishing high school English series sponsored by the Ministry of Culture and then introduced it into the compulsory high school education cycle.Though the English series was on the basis of Direct Method (DM) and Reading Method (RM) as the favorite methods around the world, there was a movement towards Situational Language Teaching (SLT) and Audio-Lingual Methods (ALM). The six textbooks of English series did not pursue a consistent procedure and design in the lessons. For instance, the reading passage in a lesson was followed by the relevant or irre levant grammar exercisesbut in another lesson, there were no follow up exercises of previous taught materials. The English textbook series included a glossary at the end of the books which provided students with English-to-Persian translation of vocabularies.

In the mid-1960s, a revolutionary reform in the ELT methodology took place through which high school English series was fundamentally revised. During 19641979, the English textbooks followed the prevalent principles of SLT, as its focus was on students' development of basic vocabulary knowledge required for future use. The respective textbooks were called "Graded English" since the content of each lesson was selected, graded, and sequenced based on a systematic procedure.In the six English textbooks of Graded English, the objectives, activities, procedures, and syllabi were all clear and consistent in all lessons (Foroozandeh, 2011).

With respect to the status of English, Pahlavi Regime (1925-79) put an emphasis onthe enhancement of Iranian students' English fluency andproficiency in compulsory education as English was known as the lingua franca of the world which contributed to the facilitation of communication and competition of Iran with modern world and European countries. During this period, based on the government's polic ies which aimed at modernizing the country through obtaining technology, knowledge, and science from America or European countries, English programs in public schools attracted policy makers' attention so that native speakers were missioned and invited to teach English to Iranian students (Safari \&Rashidi, 2015b; Zohrabi, Sabouri, \&Behroozian, 2012). Thus, to change the situation into an ideal one, they were employed to improve students' language communicative skills (Dahmardeh, 2009).

\subsection{The ELT program after the Islamic Revolution}

After the Islamic Revolution of Iran in 1979, the educational system underwent dramatic changes titled as Islamization of schools and education. The Islamic 
values and ideologies were replaced for secularism to revitalize the spiritual and religious identities of people. As Dahmardeh (2006) puts it,English was considered as a foreign language which be longed to the US. The political chaos in relationship between Iran and America had its negative effects on government's policies towards English teaching and learning. Consequently, this view led the people of higher decision-making positions to reallybelieve that English was the language of enemy. According to Safari and Rashidi (2015b), after some decades, these beliefs in the form of hindsight and biases yet exist in the educational system of Iran and affect the ELT program.

In Foroozandeh's (2011) sense, frequent reforms occurred in the Post-Revolution educational system. The first reform which took place immediately after the Revolution was a change in the educational system of primary, junior high school, and high school continuum of study as each included 5, 3, and 4 years respectively. Based on this system, English as a subject matter would begin from first grade of junior high school and continuedto grade 4 of high school. Another reform was exclusion of "Graded English Series"fromteaching cycle in 1982 and introducing "Right Path to English" textbooks in Iranian English teaching syllabi.

It should be noted that English textbook series developed for teaching in Iranian public schools (1982-2013) were based on the principles of Reading Method (RM) as adominant method of teaching in 1920-1930. Foroozandeh (2011) highlighted the aims of this series based on the introduction of the textbooks as (1) familiarizing the world with the Islamic Revolution of Iran through the use of English, (2) reaching industrial, economic, and scientific independence which demands ability to use sources and books in English, and (3) enabling students to communicate with the people living in different parts of the world.

Although the English series was developed based on the principles of RM, teachers mostly preferred teaching based on the principles of Grammar Translation Method (GTM) in schools. In English classes held in public schools, English teachers used Persian as the first language of the students to explain the lessons, content, and grammatical features. Sentences were read one by one either by the teacher or students, then their meanings were clarified or told in Persian.It is worth noting that despite the well-accepted GTM among teachers, it has its own negative effects on teaching and learning, as Sahragard and $\operatorname{Alimorad}(2013$, p. 1) also highlighted the debilitative and demotivating nature of GTM on learners' English language achievementby enumerating its reasons as "lack of self-confidence;teachers' competence and teaching styles;lack of interest in English;lack of school facilities; learning contents and context;focus on English usage; and the focus of teaching". Safari and Rashidi (2015b) also emphasized that ELT program in Iran 
has so far failed to promote learners' long life communicative abilities and prepare them for language use in authentic situations. They illuminated the reasons for this failure as textbooks, status of English in the educational system, multi-level classes, and pre-service and in-service classes.

\subsection{The ELT program after the educational reform of the late 2012}

According to Kheirabadi and AlaviMoghaddam (2014), the Ministry of Education announced a fundamental reform in 2010. The most important goal of reform was the promotion of "National curriculum of Islamic Republic of Iran" which ultimately ratified in the late 2012. The occurrence of such fundamental reform in the educational system lead to changes of grades in primary school (6 grades), junior high school (3grades), high school (3 grades). Along with this reform in 2013, the English textbook series was replaced by "English for School Series, Prospect". The respective textbook series was introduced into public schools from grade one of junior high school. Until now, three English textbooks of this series have been taught in grade one, two, and three of junior high school.

The government and policy makers, so many years after the Islamic Revolution, found the vital role of ELT in the educational system of Iran and English as an International Language.According to Kheirabadi and A laviMoghaddam (2014), it was for the first time during the age of ELT in Iranian public schools that a set of purposes and objectives for teaching English was formally designated and announced through the Ministry of Education. In fact, teaching foreign languages constituted the $11^{\text {th }}$ domain of the 12 domains which expressed the national curriculum. The $11^{\text {th }}$ domain which was devoted to ELT stated its objectives as follows:

- Teaching foreign languages should set the scene for reception, perception, and the cultural transmission as well as the scientific achievements by means of the linguistic communication;

- In addition to the intercultural and interpersonal functions, the economic developments including tourism industry, IT science, and so on should be achieved through a focus on teaching foreign languages;

- Foreign language education starts from grade 7 of junior high school, aiming at the development of four skills of listening, speaking, reading, and writing through the communicative approaches.

On the basis of the document stated in the National curriculum, domain $11^{\text {th }}$, the recommended teaching methodology was titled as "interactive self-reliance 
communicative approach" that is the localized version of CLT (Kheirabadi\&AlaviMoghaddam, 2014, p. 227) based on Iranian culture, Islamic identities, and values.

So far, three textbooks of this series named as Prospect1, Prospect 2 and Prospect 3 have been developed, published, disseminated, and used in all Iranian public schools. Right now, about four millions of students at three grades of one, two, and three of junior high school are studying these three textbooks. It is claimed by the authors of the textbooks that due to its brevity, Prospect 1 has been designed for beginner students (no knowledge of English) within the age range of 11-12 while prospect 2 is used for students with 13-14 years of age, and prospect three for students aged at 14-15 in public schools. A work book, an audio CD, flash cards, and teacher's guide are accompanied by Prospect 1, 2, and 3 respectively. The lessons are organized around the themes and functions based on what have been proposed in the Common European Framework of Reference of Languages (CEFR). The grammatical features and vocabulary are located in a part named as Key Language.

Janfeshan and Nosrati (2014)evaluated Prospect 1 to elaborateits advantages and disadvantages. It was stated that it focuses on the oral skills and communicative abilities. The grammatical features of lessons are not directly pointed to but rather taught through functions. Actually, the problem solving approach allows students to elicit the grammatical points of each lesson. Work book and audio CD materials associated with the student book help the enhancement of students' language learning. So, they can promote language ability through exposure to real life materials and everyday language functions.

With regard to disadvantages of Prospect 1, Janfeshan and Nosrati (2014) also state that it does not include any story line and has no reference to the previous notions of lessons. Written activities are also restricted to the workbook and no further activities are taught in classes. Language is completely mingled with the culture of society with no reference to the English culture. There are words in the book that have no English equivalents. The textbook also does not provide students with activities to learn beyond the book contents and materials.

\subsection{Purpose and significance of the study}

For years, ELT program of Iran under the jurisdiction of Ministry of Education has not been able to develop learners' English language profic iency in a continuum of seven-year learning,so they were required to improve their language skills through registration and participation in language classes held in private English language 
institutes. Taking a critical look at this issue, we find that millions of students who graduate every year are not sufficiently competent in English to communicatively use it in real life situations. This is the unpleasant reality of our ELT program despite the governments' investment of huge fund, money, and resources.

According to Safari and Rashidi (2015b), a number of factors and constraints are responsible for the success or failure of each ELT program within or beyond the educational system. The failure of our ELT program can be summarized in type of teaching methodology (mostly GTM), incompetent teachers, textbooks, assessment system, and so on. Due to the lack of efficiency of the previous ELT program, the ELT program underwent changes along the reform which occurred in the late 2012. The most crucial change was that of English textbooks and introduction of communicative approach as ourEnglish teaching methodology.

This study makes an attempt to explore the problems, challenges, and concerns that English teachers have had during the period of three years after the application of new ELT program in the secondary high schools. The obtained results help policy makers and governmental bodies more tangibly and reasonably disentangle the problems associated with the newly applied ELT program. Doing so contributes to the successful outcome of the ELT program which is the promotion of Iranian students' long life communicative language skills and competency.

\section{Method}

This study is a qualitativeresearch which aims to explore English teachers' problems, challenges, and constraints after ELT reform in Iranian educational system.

\subsection{Context}

This qualitative study was conducted in the ELT context of Iranian educational system which issupervised by the Ministry of Education. The new nationally administeredELT program based on the reform of the late 2012 in public schools is the focus of research.In public schools, millions of Iranian students are educated through instruction which is determined and de livered by the government and their needs and current level of their profic iency are not taken into account. In the case of English, as it constitutes one of the compulsory subject matters in the curriculum of the educational system (Dahmardeh, 2009) like other subject matters, textbooks, materials, and assessment system isalso designated and dictated by theMinistry of 
Education. Thus, teachers are necessarily obliged to follow these predetermined requirements.

\subsection{Participants}

In this study, all the participants were selected on the basis of stratified purposive sampling involving homogeneous selection which is considered as a sampling method in qualitative research (Ary, Jacobs, \& Sorenson, 2010). The researchers stopped the process of sampling when the stage of saturation was achieved and no new information was obtained. According to Kolb (2012), it is essential that data saturation be occurred to ensure the adequacy of collected information which accurately reflects the participants' views and perspectives.

Thus, we selected 35 male and female English teachers who taught English to Iranian students in public schools. The English teachers were teaching English on the basis of new ELT program and textbooks. In order to achieve more generalizable findings, we selected participants from both urban and rural areas. Thus, 18 participants were selected from rural regions and towns of Tehran, Fars, and Yazd provinces. However, other 17 teachers were selected from different cities of Iran such as Tehran, Shiraz, and Yazd (urban areas). These English teachers held B.A or M.A degree in English literature or ELT with an average of 10 years of English teaching experience in public schools. All the participants taught English based on the newly designed textbooks, Prospect 1, 2, or 3 during the three years of administration of new ELT program after the reform. To guarantee the privacy of all the participants, the researchers firstly promised not to identify or reveal their names or identities in any type of written or oral communication.

\subsection{Instrument}

To collect thick and rich data, we utilized qualitative research interview which is considered as the most crucial method of data gathering in grounded theory (Ary, Jacobs, \& Sorenson, 2010). Furthermore, the interactive nature of interviewing constitutes a component often as a practice in the grounded theory (Strauss \& Corbin, 1990). As Kvale (1996) puts it, the main purpose of interviewing is to comprehend the meaning of participants' views and uncover the meanings based on the ir experiences. Accordingly, he addsinterview lets people convey to other people a situation from their own perspectives and in the ir own words. Through interviewing, a great amount of data can be gathered (Kolb, 2012).

Actually, in this research, we preferred semi-structured guided interview over other types of qualitative interview since it is used in the form of a dialogue which is 
flexible andallowsthe skilled interviewerto elicit a great amount of in-depth data from participants for its further analysis (Lofland\&Lofland, 1995). Meanwhile, during the interview process, it gives the interviewera chance to modify and elaboratethe open-ended questions and their formats to probe and explore detailed information and what is significant about the issue at hand.

\subsection{Procedure}

One of the researchers conducted interviewswith participants separately to gain desired qualitative data concerning the problems, constraints, or concerns they had experienced with the new ELT program after the revolutionary reform. All the interviewees were free to respond to the questions in Persian or English. There was no time limit during the interview process to give the participants a chance to critically think and reflect on the questions. However, the interviewer adroitly attempted to interrupt the conversation and take the floor to shift the participants' attention to the research focus if interviewees' deviation from the main themes of research occurred. The average amount of time devoted to eachinterviewee was 45 minutes. All the interviews were conducted face to face or through telephone, as they were also recorded for transcription and further analysis.

\subsection{Data analys is}

Strauss and Corbin's (1998) constant comparative method which constitutes the core of grounded theory (Strauss, 1987; Glaser, 1992)wasadopted in the thematic analysis of data.These steps involved open coding, axial coding, and selective coding to obtain a comprehensive portrait of the information during the process of data analysis (Strauss \& Corbin, 2008).

The first phase helped the researchers to develop major or core dimensions, categories, and concepts. During axial coding as the next level of analys is, data were pieced to the relationships and connections between concepts and categories (Kolb, 2012). Thus, the researcher further analyzed the data by the use of axial coding which was the continuation of posing questions and making comparisons between categories in addition to the processes of inductive and deductive thinking of linking subcategories to the main category (Strauss \& Corbin, 2008). The final stage involved the process of identifying, developing, and selecting the core category as well as systematically relating it to other major concepts and categories. It was only through the process of important integration of merging and 
refining all major categories into a core category could the grounded theory surface(Strauss \& Corbin, 2008).

At the end of data analysis, to warrant the credibility of data, member checkingas a technique of triangulation was used to ask participants for further meaning and precision (Ary, Jacobs, \&Sorenson, 2010). Actually, it was a crucial control process in qualitative study during which participants were given the opportunity to review and examine their statements for accuracy (Harper \& Cole, 2012).The themes which emerged during the data analysis process showed Iranian EFL teachers' perspectives regarding the ir problems and concerns with the newly applied ELT program in the Ministry of Education.

\section{Key findings}

The following themes were emerged as Iranian English teachers' problems and concerns with the new ELT program through transcription and codification of the data:

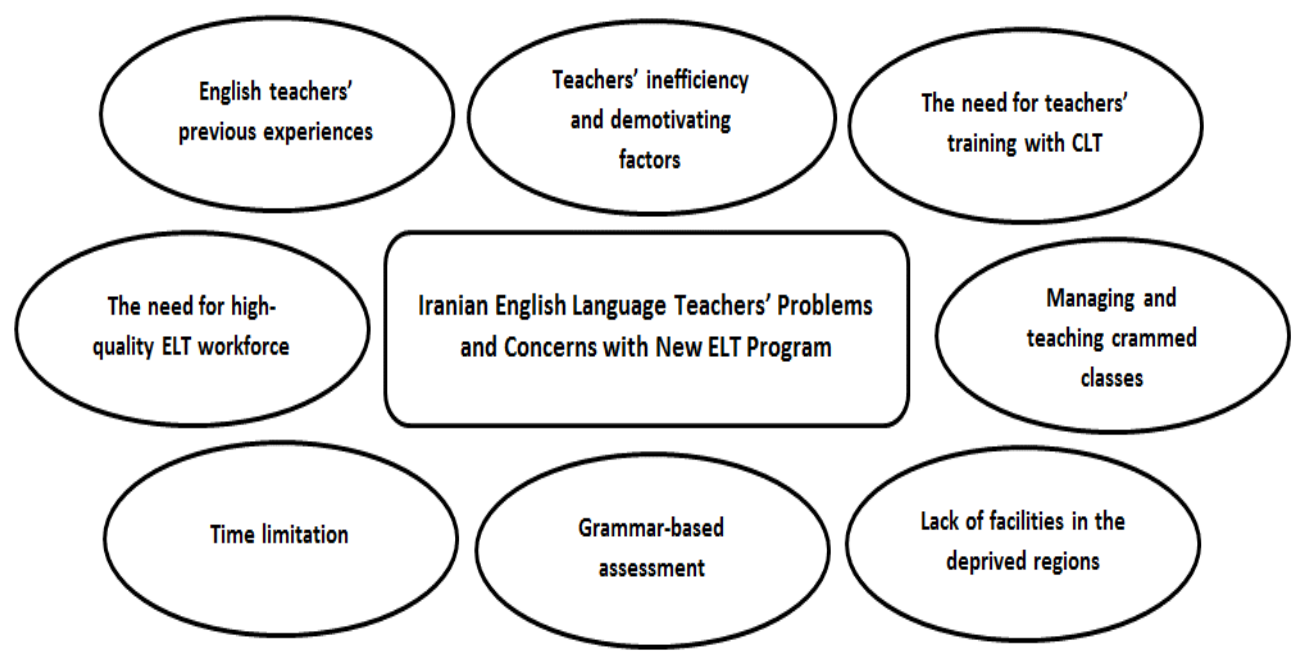

Figure 1. Iranian EFL teachers' problems and concerns with the new ELT program All these emergent themes are now thoroughly elaborated, as 


\subsection{The need for high-qualityELT workforce}

The ever-growing requirement for good communication abilities and skills in English among students has created avital demand for the quality of language teaching, ELT materials, and resources all over the world (Richards, 2006). These requirementshave recently been recognized by the Iranian government,as the occurrence of revolutionary reform in the educational system andEFL program was associated with the introduction of newly designed books and CLT approach of language teaching into the traditional language classrooms of public schools. Hence, Iranian EFL teachers were obliged to teach based on new English books through implementation of CLT to help students develop a good command of English and long life language skills to communicatively use in real life contexts.

CLT involves teaching practices that promote students' communicative competence in authentic situations (Larsen-Freeman, 2000). However, CLT theories and practices are associated with serious challenges and concerns in EFL settings (Anderson, 1993; Ellis, 1996; Li, 1998; Takanashi, 2004; Yu, 2001) so that a wide gap between policy and practice is felt in this regard (Littlewood, 2007; Nunan, 2003). One of the most significant constraints that impedes the successful implementation of CLT is an undeniable need for Englishlanguage teaching staff in Iranian public schools who are empowered with fluency, competent knowledge, and proficiency.

Although thegovernment's educational policies and curriculahave embraced CLT as the appropriate method for improving Iranian students' language skills, this aim cannot be achieved until Iranian EFL teacherspossess the essential skills, knowledge, and acceptable language competency to count on as the basis for their professional advancement and promotion of students' communicative abilities, success, and language learning (Safari \&Pourhashemi, 2015; Safari \&Rashidi, 2015b). Accordingly, Richards (2011) nicely points out EFL teachers are required to have language-specific competency such as fluency which is regarded as a significant skill. A participant said:

"We have to teach English lessons based on CLT. This method requires a fluent and competent teacher. For many years, we've been accustomed to teaching based on GTM. This has been the routine of our classes. But now, we're required to speak fluently and apply the principles of CLT. How can we do this while I think most of the English teachers cannot speak fluently? The ministry should firstly have developed the proficiency of English teachers and then made children use CLT in their classes." (Participant 5) 
With respect to this quote, English teachers were plagued by teaching syllabi and curricula foisted on them by the higher order policy makers who did not presume the EFL teachers' lack of fluency and proficiency as an impediment to English language teaching based on principles of CLT. Accordingly, Dahmardeh (2009) claims that Iranian EFL teachers are not sufficiently competent to teach based on CLT. Thus, in order to successfully develop English as a long life means for international communication at the global level among students, Iranian EFL teachers need to be equipped with the fluency and communicative skills to cope with the demands of CLT classes. Accordingly, it is suggested that Ministry of Education provides teachers with in-service communicatively-based language classes by which they not only can improve their language skills but also get familiar with teaching methodologies for implementation of CLT in schools.

\subsection{Englis $h$ te ache rs' previous experiences}

In the EFL context of Iranian public schools, most of teachers are experienced English teachers who are accustomed with the traditional approaches of language teaching such as teacher-centered approach, as Chang and Goswami (2011) claimedteachers are considered as the know ledge transmitters and learners as the receivers. As Safari and Pourhashemi (2015) put it, in the EFL context of Iranian classrooms, the asymmetrical relationship exists between teacher with the absolute power and the powerless students as the subordinates. For years, Iranian EFL teachers in public schools teach English on the basis of this teacher-dominated instruction whereby students as the passive recipients of knowledge digest the bits and pieces of knowledge passed on their minds while the newly introduced curriculum based on CLT demands a social relationship between teacher and students. The type of relationship which CLT advocates is the one which according to Brown (1994) is based on the learner-centered approach, giving learners a right to be responsible for the ir own learning and enhancing their motivation. A teacher articulated his views as follows:

"I'm an English teacher with a twenty-one year experience of language teaching. I think the previous experience which I have had with English teaching interferes with the new one. As you know, in Iranian public school, English teaching has always been summarized in terms of GTM and Reading methods. These have been the routines of our classrooms for years. So, how can you expect me to put it absolutely aside and just stick to CLT? "(Participant 18) 
Although the influence of teachers' previous experiences on teaching practices and activities is inevitable, teachers can be encouraged by the education organizations and assigned certificates or given raise in their salaries if they attempt to implement the principles of CLT in their classrooms. This end is attained through legislation ofencouraginglawsby administrative bodies in the Ministry of Education to advocate English teachers.

\subsection{Teache rs' inefficiency and demotivating factors}

"The implementation of the new ELT program depends on the extent to which a teacher has motivation and enthusiasm. When teachers are not rewarded by the ministry of education, only does a teacher with high motivation teach based on CLT method.In our ministry of education, whether you teach well or notis the same since all the teachers receive the same salary and are not encouraged by the official bodies." (Participant 8)

This teacher believes that if the newly designed textbooks are to effectively be taught based on the principles of CLT, teachers should possess motivation.It becomes crucial asthe review of literature shows despite its significance, one of the areas that remains highly neglected in SLA and TESOL is teacher motivation (Dörnyei, 2001).Teachers do to the best of their ability, if they are internally fulfilledwith their own teaching practices, acts, and performances; and also externally encouraged and rewarded by the official authorities(Safari \&Rashidi, 2015a).

According toDinham and Scott (2000), teachers are frequently motivated by dint of those matters that are intrinsic to their teaching roles while demotivation occurs through the matters that are extrinsic to the teaching task. These researchers add thatthe main demotivators in the educational context involve the pace and nature of change in education, society's downgrading mentality towards teachers and teaching profession, teachers' negative image portrayed through media, teachers' workload, and lack of services to support teachers. As Dörnyei (2001) believes, although teachers are intrinsically motivated in many educational contexts of the world, the detrimental factors which act as the potential demotivators erode and weaken teachers' intrinsic motivation. Demotivation is also linked w ith five major factors such as "stressful nature of work, inhibition of teacher autonomy, insufficient self-efficacy, content repetitiveness, and inadequate career structure" (p. 165).

The Iranian teachers work in an educational milieu in which demotivation factors abound.These factors which unfavorably affect teachers' efficiency and effectiveness include teachers' economic conditions and low salary, having second 
job to meet their expenses, workload and pressure, the society's negative attitudes towards teaching profession as a less prestigious job, very low social status, and lack of support on the part of government or otherorganizations. In such educational environment, it makes no sense to accept that English teachers make any effort to put the new ELT program into practice and teach based on the requirements of the Ministry of Education. This lack of motivation causes English teachers to use previous routines disguised in the newly designed textbooks. As one of them said:

\begin{abstract}
"The textbooks have changed but not our teaching methodology. Although the text books are conversation-based, we follow our previous teaching most of the time. I mean translation of words and sentences into Persian, reading, grammar-based exam, and etc. I think it's ridiculous to fully devote yourself to a system which does not value your effort and support you. When your salary is no different with the salary you received prior to the new ELT program, no one tends to teach based on CLT. The new ELT curriculum requires energetic and enthusiastic teachers to develop communicative skills in students. This end is impossible unless teachers are economically supported, sufficiently praised, and valued in the society."(Participant 28)
\end{abstract}

\title{
4.4The need for te achers' training with CLT
}

One of the key factors which successfully leads to the development of language curriculumis the constructive role of EFL teachers. Teachers as the agents of change can effectively contribute to this process if they areconsciously equipped with the knowledge base of language teaching includingpedagogical practices, professional skills, and theoretical understandings through participation in dynamic teacher training courses. Accordingly, to implement the pedagogical reform in the realm of ourlanguage teaching, ELT educational system needs skillful teachers who adeptly know how to deal with the pedagogical challenges and dynamics of language situation.

In fact, the effective implementation of innovative pedagogy depends on how the educational policy makers and governmental bodies of the Ministry of Education provide opportunities for English teachers to professionally and pedagogically be (re)trained and prepare themselves in in-service classes. Ghanbari and Ketabi (2011) state that Iranian EFL teachers who have been experts in the traditional method of Grammar-translation, may suddenly be confronted with the communicative pedagogy and be asked to deploy it to their routinized class 
activities. This abrupt transition impacts teachers' confidence and consequently causes them to adopt conservative attitudes in their teaching. According to Carless (1999), in the case of lack of enough (re)training, even those teachers who were firstly enthusiastic about the innovation will become discouraged and frustrated by the constraints and problems in its implementation and ultimately turn against the program. Accordingly, an English teacher commented as follows:

"One of the problems that we have experienced with this system has been the lack of preparation for the communicative-based teaching. We need to be trained in teaching training courses. But there are also some problems with these classes. They are rarely held through the education organization or their time is very inappropriate so that we are not able to attend the class. All of us work from morning to afternoon, 6 to 8 hours a day. When we get home, we are very tired and we are not able to participate in the in-service classes that are held in the evenings. Another problem is the nature of these classes which does not have any effect on our teaching because most of them involve lecturing about the theoretical issues of teaching and methodology or even they are grammar-based. With the different problems and concerns which are associated with the new language program, I prefer the traditional method of translation. Some of my friends don't like the CLT method. They teach based on their previous method yet."(Participant 27)

This teacher's comment shows that thenumber and allotted time to such Iranian teacher training courses are not sufficient to meet teachers' needs based on the recurrent changes in curricula. The transmission based nature of these classes is not also congruent with teachers' needs since what currently seems to be important for Iranian teachers is to experience thepractical aspects of pedagogy.Therefore, it is necessary that Ministry of Education provide teachers with sufficient teacher training courses. However, as Safari and Rashidi (2015a) believe, one of the persistent problems with teacher training courses is the paucity of highly proficient and expert educators. That is, the educators involved in training EFL teachers should be fully competent individuals whomake any effort to increase teachers' professional development and growth, providing them not only with the theoretical knowledge and latest language learning advancements but also with the tangible pedagogical practices andpracticalguidance.Thus, it is suggested that educators make an emphasis on the practical considerations of ELT program and shift the ir role from transmitter of theories, knowledge, and information or educator-fronted pedagogy in Kumaravadivelu's (2012) sensetowards the facilitator of the process through which teacher's professional growth and transformation occur. 
Further, the process of teacher training and updating their knowledge is facilitated through cooperative and supportive relationships in the whole system of countries. As Ashari and Zarrin (2014) state, school principals are also required to make commitments towards giving time and opportunities to teachers to regularly attendteacher training classes.In addition to in-service teacher training classes, EFL teachers can enhance their professional knowledge and skills through ELT conferences, workshops, and seminars that are held through the cooperation between education organizations and universities. In case the ministry is not able to provide these opportunities, instructional CDs, films, or online training courses should be planned to compensate for this deficiency.

\subsection{Managing and te aching crammed classes}

"Each class that I teach includes many students, above 30 in number. How can I teach well when the classes are so populated, noisy, and multilevel? I confront several challenges at the same time. At first, I should control and manage the class. Since my students are not at the same language level, I should choose the type of instruction which is suitable to both strong and weak students. As you know, this is a very difficult job. And I'm expected to involve all the students in class activities, something which is impossible in reality. I think the newly introduced textbooks are appropriate for less populated and homogenous classes." (Participant 34)

In most Iranian public schools, 30-35 studentslive in each class (Dahmardeh, 2009) so in such EFL milieu, the provision of communicative activities, tasks, and practices becomes very demanding and impossible. An EFL teacher is required to deal not only with the management and control ofcrammed classes but also with the planning and implementation of CLT practices and materials which appropriately suit to the multilevel language classes.In this regard, Safari and Rashidi (2015b) believe that teachers in such classes need time, experience, teacher collaboration, training, and program support to meet these challenges. The official authorities and decision makers in the Ministry of Education should take appropriate actions to support teachers through making policies that restrict the number of students in each class. Teacher training programs can also be of high assistance as through participation in these classes, teachers can gain information about how to cope with these concerns.

In sum, good teaching is not just summarized at the application of communicatevely based language curriculum and content but it also involves a number of 
peripheral factors and constraintsthat an astute EFL teacher can perceive and recognize in the dynamics of language context. Actually,teaching in crammed multi-level classes is not aneasy job to blindfoldedly be performed.

\subsection{Time limitation}

One of the constraints that inhibits the operationalization of CLT curriculum in the context of Iranian public schools is the allottedtime to EFL classes. In a research conducted by Dahmardeh (2006), it was shown that nearly all participants asIranian English teachers were unsatisfied concerning the time allocated to language classes. He believes (2009) that in Iran, the time of English classes is very limited as compared with other countries. Accordingly, Ashari and Zarrin (2014) state that Iranian teachers do not have adequate time to even cover the instructional materials determined by the Ministry of Education.

While the reform has occurred in the ELT program and changed the textbooks and language curriculum, the time devoted to language teaching and learning has not undergone any change.In order to effectively and fruitfully accomplish the requirements of communicatively based language curriculum and implement CLT activities and practices, English teachers are in vital need of sufficient time. It is worth noting one of the participants' beliefs in this regard:

"I teach two grades of one and two of secondary school. I should teach based on communicative method. How can I do while the class time is three hours a week? When I use some activities such as pair work or group work, the time is getting over and I cannot cover the textbook budget. Thus, in the following sessions, I have to follow the same traditional system of teaching to compensate for the wasted time." (Participant 17)

Based on this comment, a problem that Iranian English teachers are required to challenge with is how to cope with the limitation of time in language classes. Sometimes, this concern is resolved as they resort to the traditional GTM which is easy to follow and save the time. Thus, official bodies, policy makers, curriculum planners, and program developers are suggested to focus on this important issue and devote further time to English as a subject matter in public schools if the goal is to promote students' communicative languageprofic iency. 


\subsection{Grammar-based assessment}

A number of Iranian researchers (Dahmardeh, 2006; Yarmohammadi, 2000; Bagheri, 1994; Moradi, 1996; Rahimi, 1996; Saadat,1995; Zanganeh, 1995) have found that communicative skills have been ignored in Iranian educational system, as the emphasis of education is on students'achievement; hence, teachers make any attempt to tailor the curriculum according to the grammar-based exams.Concerningthe importance of achievement standards, Dahmardeh (2006) mentioned Iranian EFL teachers feel pressure to prepare students for exams based on the test contents. Thus, they narrow the curriculum and teach to the language tests which do not reflect communicative based language instruction.

While the new ELT program of Iran focus on communicatively-oriented instructional activities and interactional practices and implicitly discourages a focus on drills, memorized structures and detailed explanations of English forms in Persian, the system of assessment has not undergone any change and yet it pursues the traditional standards and criteria, emphasizing memorization of materials, structure-based activities, and decontextualized vocabularies.Thus, the development of teaching and learning communicative abilities becomes an unattainable goal unless the system of exam is transformed.A participant expressed his opinions as follows:

"We are required to deploy CLT in our classes. But the final achievement examinations are totally based on grammar features, structures, vocabularies, and reading comprehension texts. There is no focus on the oral skills in the exams even the dialogues and pronunciation are in written form. So, in my opinion, it is meaningless to apply communicative principles while the exam focuses on something else." (Participant 31)

In this participant's sense, it is futile to operationalize CLT due to grammar-based exams of public schools. Thus, it becomes imperative that educational policy makers outline the agendas of assessment system based on CLT principles and practices to shift thetesting paradigm from traditional or paper-and-pencil mode towardscommunicative-based assessment system. In so doing, teachers' roles change from the authorities of language classrooms to the facilitators of language learning and communication process who take not only the written mode of language testing but also the oral mode into account. In that case, the goal of instruction and realities of language classrooms conform to those of assessment policies and criteria. 


\subsection{Lack of facilities in the deprived regions}

Successful governmental policies for language learning and teaching at the national levelare pertinent to how well various factors and barriers are predicted and taken into account. A hurdle which inhibits the nationwide realization and operationalization of the new ELT programis lack of facilities, services, and resources in small towns, villages and poor regions of Iran. The new textbooks which are communicatively and interactionally oriented have been designed on the basis of students' access to numerous resources including private language institutes, English books,fluent and competent teachers, CDs, films, electronic instruments, and technologies. The new ELT system only considers and pays attention to the needs of middle class students who live in large cities of Iran and enjoy different facilities both in schools and home.

Actually, it is very painful when we think of poor students who live in a small village with no facilities and attend the English classes of public schools based on this system. The English class becomes a nightmare and in Tsui's (1996) sense, an extremely anxiety-provoking milieu for most of them, associated with the negative feelings and attitudes such as fear, embarrassment, hate, disappointment, and stress. When they begin learning English in public schools, they are expected to be at a threshold level of English proficiency; for instance, to know English alphabetic letters, sounds, dictation, and some expressions. Except English classes of public schools, no language classes are available to these students to achieve this threshold level of English. An English teacher who taught in a public school of a very deprived village explained:

"I teach in a village in which the people are very poor. The students from the low-income families attend the English class with blank minds. They have never heard an English sentence orally. School does not have the facilities which are necessary for a language class such as CD players, high quality CDs, films, a library, and flash cards. To work based on CLT is a burden for me because the time of class is very limited. If I want to teach based on CLT, I need more time and facilities. In my opinion, the ministry should resolve these problems; otherwise, the new ELT program is of no use. It just creates anxiety and stress in students." (Participant 13)

The policy actions should be taken to support the students who study in poor regions and are deprived of any facilities and high-quality teaching in comparison to students of the same age living in big cities of Iran. The students in high- poverty settings have this right to equally have access to facilities and good teaching.Thus, 
in addition to the provision of facilities, good teaching in such contexts is another issue which should be taken into account. As Coley (2013) puts it, keeping teachers in high-poverty schools might require higher payment, benefits, and other incentives. In sum,it is suggested that governmental policy makers of ELT education and the ministryshould have a focus on targeting maximum funding to this end and equally distribute the resources, services, and opportunities in all educational settings.

\section{Conclusion}

Inadequacy and limitations of the preceding ELT education of Iran in promoting students' language skills and communicative abilities in addition to the recognition of fundamental role of English as the international language of communication, science, and technology at the global level urged the government to make a revolutionary reform in the English language program of the Ministry of Education. Thus, through this reform, new textbooks which were designed on the basis of conceptions and principles of CLT replaced for the previously structurebased textbooks. However, the inception of reform was accompanied by teachers' negative feedback, expressing concerns, problems, and constraints of implementation of the new ELT program. This paper, in fact, made an attempt to explore Iranian English teachers' viewpoints regarding challenges they faced in the context of language classroom by application of the innovative pedagogy.

The findings of this paper confirmed if the new English language reform and policy turn out to be successful at the national level, the government is necessarily required to take actions towards the elimination of potential impediments which block the materialization of the new curriculum. The insightful results of research is of highly paramountsignificance to official bodies, policy makers of education, textbook developers, decision makers, educators, and EFL teachers. Actually, a consciousness awareness of the possible constraints appropriately helps all ELT stakeholders to take actions towards the betterment of language curriculum in Iranian public schools.

\section{References and notes:}

Anderson, J. (1993). Is the communicative approach practical for teaching English in China? Pros and cons. System, 21, 417-480.

Ary, D., Jacobs, L.C., \& Sorenson, C. (2010). Introduction to Research Education ( $8^{\text {th }}$ Ed.) New York, NY: Wadsworth. 
Ashari, N., Zarrin, N. (2014). Problems in Using Communicative Language Teaching in Iran and Possible solutions. Technical Joumal of Engineering and Applied Sciences, 4(4), 257-266.

Aslanabadi, H., \&Aslanabadi, Sh. (2013). Crucial need for communicative approaches and intercultural communication in teaching English at Iranian schools in government sector. International Review of Social Science and Humanities, 6( 1), 161-167.

Bagheri, H. (1994). A profile for teaching and teaching English in pre-university schools of Sistan and Baluchestan: Problems and solutions. Unpublished Master's Thesis, Shiraz University, Shiraz.

Brown, H. D. (1994). Teaching by principles: An interactive approach to language pedagogy. Upper Saddle River, New Jersey: Prentice Hall Regents.

Carless, D. R. (1999). Large-scale curriculum change in Hong Kong. In C. Kennedy, P. Doyle, \& C. Goh, (Eds.), Exploring change in English language teaching (19-29). Oxford: Macmillan Heinemann English Language Teaching.

Chang, M., \&Goswami, J. S. (2011). Factors Affecting the Implementation of Communicative Language Teaching in Taiwanese College English Classes. English Language Teaching, 4(2), 3-12.

Coley, R. J., \& Baker, B. (2013). Poverty and Education: Finding the Way Forward. ETS Center for Research on Human Capital and Education Research and Development Educational Testing Service, Rosedale Road Princeton, NJ 08541-0001

Dahmardeh, M. (2006). A Preliminary research on textbook evaluation: How to make the Iranian secondary school's English language textbooks communicative? University of Lancaster, Lancaster, Great Britain.

Dahmardeh, M. (2009). English language teaching in Iran and communicative language teaching. A thesis for the degree of Doctor of Philosophy in education .The university of Warwick.

Dinham, S. \& Scott, C. (2000). Moving into the third, outer domain of teacher satisfaction. Journal of Educational Administration, 38(4), 379-396.

Dörnyei, Z. (2001). Teaching and Researching Motivation. Essex: Pearson Education Limited.

Ellis, G. (1996). How culturally appropriate is the communicative approach? ELT Journal, 50(3), 213-218.

Foroozandeh, E. (2011). History of High School English Course Books in Iran: 1318-1389 (1939-2010). Roshd Foreign Language Teaching Journal, 13 (4), 37-44.

Fterniati, A. (2006). National curriculum reform and new elementary school language arts textbooks in Greece. International Journal of Learning, 13(4), 37-44.

Ghanbari, B., Ketabi, S. (2011). Practicing a Change in an Iranian EFL Curriculum: from Ivory Tower to Reality. Iranian EFL Journal, 7 (6), 9-13.

Ghorbani, M. R. (2007). ELT in Iranian high schools in Iran, Malaysia and Japan: Reflections on how tests influence use of prescribed textbooks. Reflections on English Language Teaching, 8(2), 131-139.

Glaser, B. G. (1992). Emergence vs. Forcing. Basics of Grounded Theory Analysis. Mill Valley: Socio logy Press.

Harper, M., \& Cole, P. (2012). Member checking: Can benefits be gained similar to group therapy? The Qualitative Report, 17(2), 510-517.

Janfeshan, K., \&Nosrati, M. (2014). A quick look to English language training in Iranian guidance schools through "Prospect" method and CLT with a book analytic approach. International Joumal of Economy, Management, and Social Sciences, 3(1), 100-106. 
Kheirabadi, R., \&AlaviMoghaddam, S. B. (2014). New horizons in teaching English in Iran: A transition from reading-based methods to communicative ones by" English for Schools" series.International Journal of Language Learning and Applied Linguistics World (IJLLALW), 5 (4), 225-232.

Kolb, Sh. M. (2012). Grounded theory and the constant comparative method:Valid research strategies for educators. Journal of Emerging Trends in Educational Research and Policy Studies (JETERAPS), 3 (1), 83-86.

Ku maravadivelu, B. (2012). Language teacher education for a global society: A modular model forknowing, analyzing, recognizing, doing, and seeing. New York, NY: Routledge.

Kvale, S. (1996). Interviews: An Introduction to Qualitative Research Interviewing. California: Sage Publications.

Larsen-Freeman, D. (2000). Techniques and principles in language teaching. Oxford: Oxford University Press.

Li, D. (1998). It's always more difficult than you plan and imag ine: Teachers' perceived difficulties in introducing the communicative approach in South Korea. TESOL Quarterly, 32(4), 677-703.

Littlewood, W. (2007). Communicative and task-based language teaching in East Asian class rooms. Language Teaching, 40, 243-249.

Lofland, J., and Lofland, L.H. (1995). Analyzing Social Settings: A Guide to Qualitative Observation and Analysis, 3rd Ed. Belmont, CA: Wadsworth.

Moradi, F. (1996). An Investigation into the problems of teaching and learning English in Tehran province. Unpublished Master's Thesis, Shiraz University, Shiraz.

Nunan, D. (2003). The impact of English as a global language on educational policies and practices in the Asian-Pacific region. TESOL Quarterly, 37(4), 589-613. Pacek, D. (1996). Lesson to be learned from negative evaluation. ELT Journal, 50(4), 335-341.

Rahimi, M. (1996). The study of English language instruction at the secondary schools of the Isfahan province. Unpublished Master's Thesis, Shiraz University, Shiraz.

Rena, R. (2008). Financing education and development in Eritrea: Some implications. Man power Journal, 43 (1), 73-97.

Rena, R. (2011). Challenges for Quality Primary Education in Papua New Gu inea: A Case Study. Education Research International, 2011, 1-11.

Richards, J. C. (2006). Communicative Language Teaching Today. New York: Cambridge University Press.

Richards, J. C. (2011). Competence and performance in language teaching. New York: Cambridge University Press.

Saadat, M. (1995). An investigation into the problems of teaching and learning English in the guidance and high schools of Fars province. Unpublished Master's Thesis, Shiraz University, Shiraz.

Safari, P., \&Pourhashemi, M.R. (2015). Toward an empowering pedagogy: Is there room for critical pedagogy in the educational system of Iran. In A. Darder, P. Mayo, \& J. Paraskeva (Eds.), International Critical Pedagogy Reader. London: Routledge, Taylor \& Francis. (in press)

Safari, P., \&Rashidi, N. (2015a). Teacher education beyond transmission: Challenges, concerns, and opportunities for Iranian EFL teachers. Issues in Educational Research, 25(2), 187-203. http://www.iier.org.au/iier25/safari.html

Safari, P., \& Rashidi, N. (2015b). A critical look at the EFL education and the challenges faced by Iranian teachers in the educational system. International Journal of Progressive Education,11 (2), 14-28. 
Sahragard, R., \&Alimorad, Z. (2013). Demotivating factors affecting Iranian high school students' English learning. Retrieved June 05, 2015 from http://works.bepress.com/zahra alimorad/6

Strauss, A. L. (1987). Qualitative Analysis for Social Scientists. Cambridge: Cambridge University Press.

Strauss, A., \& Corbin, J. (1998). Basics of Qualitative Research. Techniques and Procedures for Developing Grounded Theory. London: Sage.

Strauss, A., \& Corbin, J. (2008). Basics of Qualitative Research: Techniques and Procedures for Developing Grounded Theory. London: Sage.

Takanashi, Y. (2004). TEFL and communication styles in Japanese culture. Language, Culture and Curriculum, 17(1), 1-14.

Tsui, A. B. M. (1996). Reticence and anxiety in second language learning. In K. M. Bailey $\&$ D. Nunan (eds.). Voices from the language classroom. Cambridge: Cambridge University Press, 145-167. u mn.edu/NCEO/Online Pubs/Tech44/

Yarmohammadi, L. (2000). Reflections on the Treatment and Contextualization of Pronunciation Practices and Language Functions in the Pre-university textbooks in Iran. Journal of Teaching Languages, 1 (3), 1-21.

$\mathrm{Yu}, \mathrm{L}$. (2001). Communicative language teaching in China: Progress and resistance. TESOL Quarterly, 35(1), 194-179.

Zanganeh, M. 1995. Analysis of Problems of Teaching and Learning English in the High Schools of the Kermanshah Province. Unpublished M.A. Thesis. Shiraz University, Shiraz.

Zohrabi, M., Sabouri, H., \&Behroozian, R. (2012). An assessment of strengths and weaknesses of Iranian first year high school English course book using evaluation checklist. English Language and Literature Studies, 2(2), 89-99.

\title{
Summary
}

\section{Iranian EFL Teachers' Challenges with the New ELT Program after the Reform: From Dream to Reality}

\author{
Parvin Safari \\ Shiraz University, Iran \\ Rahman Sahragard \\ Shiraz University, Iran
}

There is no doubt concerning the interdependence of educational progress with human development, socio-economic growth, greater opportunities, welfare, and political stability. Hence,for further development and growth of education,transformations and reforms in curriculum are required to reflect the latest changes in theories and praxis of the modern world (Fterniati, 2006). In Iran, due to the inadequacy of the preceding ELT education policies in developing students' communicative skills and capabilities, a reform occurred in the ELT program as new communicative based textbooks entitled as "English for School 
Series" and CLT pedagogywere introduced into the context of public schools. However, implementation of the innovative curriculum was associated with different feedback from English teachers. This qualitative study is, indeed, an attempt to explore concerns, problems, and constraints that EFL teachers experienced through the revolutionary reform of the ELT education. Thus, based on stratified purposive sampling, the researchers selected 35male and female teachers of English at grades one and two of junior high schools from both urban and rural regions of Tehran, Shiraz, and Yazd, Iran.The researchers usedtranscription and codification of data gathered through semi-structured interview to find the emergent themes concerning teachers' challenges and problems in Iran. The findings also indicated that if the new English language reform and policy turn out to be successful at the national level, the government is necessarily required to take actions towards elimination of the potential impediments which block the materialization of the new curriculum.

Key Words: ELT education; Commun icative skills; Revolutionary reform; Semi-structured interview; Innovative curriculum. 